\title{
KEPEMIMPINAN: SUATU TINJAUAN MANAJEMEN SUMBER DAYA MANUSIA
}

\author{
Januar Heryanto ${ }^{1}$
}

\begin{abstract}
Leadership qualities might naturally "inborn" to some people, but for some others have to make efforts to grow the leadership qualities in themselves. It's wellknown as a "formed-leaders", leadership that grows through examples and experiences. Leaders should have a vision to see the future from the distance. They dream is not only about what can be happened to day, but also about what will happen in next year, in next decade, even in next generation.
\end{abstract}

Keywords: leadership, vision, influence

ABSTRAK
Walaupun kualitas kepemimpinan mungkin secara alamiah melekat pada
sebagian orang, yang biasanya disebut pemimpin yang dilahirkan, namun sebenarnya
bagi sebagian orang lain kepemimpinan mereka bertumbuh dalam hidup mereka. Inilah
yang disebut pemimpin yang dibentuk, yang bertumbuh melalui pengalaman mereka.
Para pemimpin harus memiliki visi untuk melihat apa yang akan terjadi di masa depan.
Mereka memimpikan bukan saja apa yang dapat terjadi sekarang, tetapi juga apa yang
dapat terjadi tahun depan, sepuluh tahun mendatang bahkan yang akan terjadi pada
generasi berikutnya.
Kata kunci: kepemimpinan, visi, pengaruh

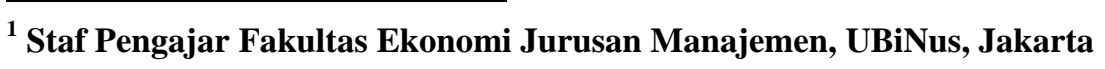

Kepemimpinan: Suatu Tinja ua n ... (J a nuar Heryanto) 


\section{PENDAHULUAN}

Dewasa ini, persoalan yang dihadapi sejumlah institusi baik di dunia pendidikan, bisnis, industri, politik maupun pemerintahan adalah krisis kepemimpinan, yang sudah mulai terasa sejak abad ke duapuluh. Kita memang memiliki pemimpin formal, yaitu mereka yang memiliki posisi pemimpin di bidang pendidikan, bisnis, industri, pemerintahan, sosial, religius dan sebagainya, tetapi tidak jarang terjadi banyak institusi yang mengecewakan kita, karena ulah pemimpinnya. Kadang-kadang, istilah kepemimpinan bagi sebagian orang dapat rancu, karena seseorang yang menduduki posisi formal dalam sebuah institusi tidak selalu menjadi pemimpin. Kepemimpinan tidak identik dengan posisi formal atau jabatan. Bila pejabat yang mengepalai sebuah institusi tidak melaksanakan fungsi kepemimpinan, maka dia tidak layak disebut pemimpin. Di setiap jaman, selalu lahir seorang pemimpin yang akan memenuhi kebutuhan pada jaman itu. Tidak ada seorang pemimpin yang potensial yang tidak mempunyai kesempatan untuk berkarya di tengah masyarakat. Jadi selain kemampuan untuk memimpin, dibutuhkan momentum yang tepat untuk melahirkan seorang pemimpin. Martin Luther King Jr, Mahatma Gandhi, Soekarno adalah contoh-contoh pemimpin yang lahir pada saat yang tepat.

Beberapa orang lahir ke dunia ini dikaruniai rasa percaya diri dan otak yang cemerlang. Jelas hal ini merupakan suatu keuntungan. Tetapi sebagian besar orang menjadi pemimpin yang lebih baik melalui serangkaian kegiatan yang spesifik. Lebih banyak jumlah pemimpin yang "dibentuk” dari pada jumlah pemimpin yang “dilahirkan”. Salah satu bukti bahwa pemimpin dapat dibentuk dari orang-orang "biasa” adalah catatan riwayat personel Korps Marinir AS. Calon marinir yang direkrut sebagian berasal dari rumah tangga yang bermasalah dan berantakan. Tidak jarang mereka pengguna obatobatan terlarang dan pecandu alkohol atau memiliki pAndangan sempit. Semua ciri yang dapat digunakan untuk meramalkan kesuksesan pada umumnya jarang didapatkan pada kelompok individu ini. Namun banyak dari antara calon marinir yang direkrut ini menjadi pemimpin yang efektif setelah mereka menyelesaikan pendidikannya dan selanjutnya terus menunjukkan keterampilan kepemimpinan yang luar biasa ketika karier mereka berlanjut (Zenger, 2004).

Bakat alamiah dan ambisi semata tidak selalu membawa keberhasilan jangka panjang. Sebuah perusahaan yang diberitakan berada pada urutan teratas dalam "Daftar perusahaan per-bank-an paling dikagumi” di majalah Fortune, yakni J.P. Morgan, banyak karyawan muda yang memulai tugas baru meluncur cepat lewat jalan meteor di langitlangit Morgan. Pada mulanya mereka bersinar cemerlang dalam tugas-tugas pengolahan data numerik, namun kemudian secara spektakuler kehadapatn nyala ketika menghadapi tantangan tugas-tugas yang menuntut kematangan (mature) yang integral dengan kepemimpinan perusahaan. Sejumlah orang terlalu takut membuat keputusan besar, yang lain menakut-nakuti siapa saja yang berani mengambil keputusan tanpa mereka. Beberapa karyawan muda yang lain merupakan manajer hebat sejauh mereka melakukan 
menajemen angka. Perbendaharaan manajemen mereka tidak merentang sampai ke urusan memikirkan dan merasakan manusia, yang tidak mudah dimanipulasi seperti program komputer untuk accounting. (Lowney, 2005) Biasanya pemimpin yang baik, didorong oleh suatu visi. Tetapi apakah visi itu? Dr. David George, dalam kuliah umumnya di depan para sivitas akademika U.K Petra pada akhir tahun 2004 mengatakan bahwa visi adalah melihat masa depan, saat ini, didasari oleh masa lalu atau tepatnya melihat yang tidak kelihatan dan menjadikannya dapat dilihat. Visi adalah gambaran yang ada dalam mata pikiran tentang hal yang dapat atau seharusnya terjadi di masa depan.

\section{PEMBAHASAN}

\section{Definisi Kepemimpinan dan Pengaruh}

Pengertian kepemimpinan berdasarkan pencarian di situs search engine Google (dengan kata kunci "kepemimpinan”) diperoleh hasil lebih dari sepuluh juta jawaban. Sebuah toko buku "online" menawarkan lebih dari sepuluh ribu judul tentang tema "kepemimpinan”, namun tak satupun di antara buku itu menggambarkan bahwa di tengah masyarakat berlimpah kepemimpinan. Sebaliknya, banyak di antara karya itu memperkuat apa yang secara intuitif sudah kita ketahui bahwa kita memerlukan kepemimpinan yang lebih berprinsip dan lebih efektif. (Lowney, 2005). Maxwell dalam bukunya "Developing The Leader Within You" mengatakan bahwa setelah mengamati kepemimpinan di dalam keluarganya dan bertahun-tahun mengembangkan potensi kepemimpinannya sendiri, sampai pada suatu kesimpulan bahwa "kepemimpinan adalah pengaruh". Kebanyakan orang mendefinisikan kepemimpinan sebagai kemampuan untuk meraih suatu kedudukan, bukan untuk mendapatkan pengikut. Karena itu, mereka mengejar kedudukan, pangkat, atau jabatan dan setelah berhasil mereka berfikir bahwa mereka sudah menjadi pemimpin. Tipe pemikiran ini menciptakan dua masalah berikut.

1. Mereka yang memiliki status pemimpin sering mengalami frustasi karena kurangnya pengikut.

2. Mereka yang tidak punya jabatan resmi mungkin tidak dapat melihat dirinya sebagai pemimpin dan dengan demikian tidak mengembangkan keahlian kepemimpinannya.

Kita masing-masing mempengaruhi dan dipengaruhi orang lain. Berarti kita semua sedang memimpin dalam beberapa bidang dan dipimpin dalam bidang lainnya. Pemimpin terkemuka dari suatu kelompok akan mudah ditemukan. Perhatikan saja orangorang ketika mereka berkumpul. Bila suatu persoalan harus diputuskan, siapa orang yang pendapatnya tampak paling berharga? Siapa orang yang paling diperhatikan orang-orang lain ketika persoalannya sedang dibicarakan? Siapa orang yang cepat disetujui oleh orang-orang lain? Jawaban terhadap pertanyaan itu akan membantu kita menemukan siapa pemimpin dalam kelompok tersebut. 


\section{Kepemimpinan Berawal dari sebuah Sikap}

William James, pelopor psikologi modern menulis bahwa manusia dapat mengubah hidup mereka dengan cara mengubah sikap berpikirnya. Sikap kita akan menentukan tindakan kita. Tindakan kita akan menentukan pencapaian-pencapaian kita. Prinsip ini dapat dikembangkan bahwa kita harus menata hati kita lebih dahulu sebelum kita menata hidup kita. Dari kedalaman hati manusia yang penuh dengan kejahatan akan muncul hal yang jahat, sedangkan dari kedalaman hati manusia yang penuh dengan kebaikan akan muncul hal yang baik. Jadi penentunya adalah apa yang ada di dalam batin manusia. Perubahan sejati terjadi dari dalam ke luar. (Maxwell, J. C., Buku Catatan 3, Million Leaders MAndate).

Dalam banyak situasi, peperangan sudah dimenangkan sebelum perang itu sendiri dimulai. Semuanya berkenaan dengan kerangka pikir kita ketika kita memasuki medan laga. Apakah kita penuh dengan pengharapan dan optimisme atau bersikap negatif dan meragukan keberhasilan kita? Sebuah tim bola basket yang akan bertanding hampir dapat dipastikan akan menang, bila semua anggota tim yakin mereka akan menang. Sikap kita menentukan apakah kita akan menang atau kalah. Seorang pemegang medali emas dalam sebuah Olimpiade pernah berkata, "Saya percaya bahwa satu-satunya perbedaan antara para peraih medali emas dan perak adalah sikap mereka, bukan kemampuan mereka". Seorang salesman sepatu dikirim ke sebuah negara yang jauh dan setelah beberapa hari, ia mengirim pesan: "Saya mau pulang, tidak ada orang yang pakai sepatu di sini". Seorang salesman yang lain dikirim oleh perusahaan ini untuk mengunjungi negara yang sama. Setelah beberapa hari, ia menulis pesan ke kantor di negaranya, "Kirim lebih banyak sepatu! Belum seorangpun pakai sepatu di sini!” Situasinya sama, namun perspektif (cara pAndang)-nya berbeda. Perbedaan utama antara seorang pengikut dan seorang pemimpin adalah perspektifnya. Perbedaan antara seorang pemimpin dan seorang pemimpin yang efektif adalah perspektif yang lebih baik.

Para pemimpin tahu bahwa sikap akan menciptakan momentum, positif atau negatif. Para eksekutif dalam bisnis berkata bahwa unsur penting dalam diri karyawan yang berpotensi meliputi hal berikut.

1. $5 \%$ kesediaannya (availability)

2. $5 \%$ hal dapat menyesuaikan dirinya (adaptability)

3. $10 \%$ kemampuannya (ability)

4. $10 \%$ penampilannya (appearance)

5. $70 \%$ sikapnya (attitude)

Perhatikan betapa pentingnya sikap, baik di dalam diri para pemimpin maupun anggota-anggota timnya. Seorang psikolog praktis mendaftar lima aturan untuk mengevaluasi orang yang akan dipertimbangkan untuk dipromosikan dalam pekerjaannya, antara lain sebagai berikut.

1. Ambisinya.

2. Sikapnya terhadap kebijakan. 
3. Sikapnya terhadap rekan kerja.

4. Keterampilan kepemimpinannya.

5. Sikapnya terhadap tekanan yang ada dalam pekerjaan.

Kita tidak dapat merancang dan mengendalikan sepenuhnya situasi-situasi hidup dan kepemimpinan kita, namun kita dapat merencanakan dan mengendalikan sikap kita agar siap dibentuk saat diperlukan. Di bawah ini adalah pedoman untuk merencanakan dan mengendalikan sikap Anda.

1. Percayalah, yang terpenting bukannya apa yang terjadi terhadap diri Anda, melainkan apa yang terjadi di dalam diri Anda (it is not what happens to you, but what happens in you).

2. Berhentilah menyalahkan sesuatu atau seseorang karena sikap Anda.

3. Evaluasilah sikap Anda saat ini.

4. Ingatlah bahwa iman lebih besar dari pada ketakutan.

5. Singkapkan dan tulislah sebuah pernyataan tujuan

6. Daftarkan pertolongan dari mitra Anda yang dapat dipercaya

7. Luangkan waktu bersama-sama dengan orang yang tepat

8. Pilihlah seorang model untuk diteladani

9. Isi diri Anda penuh dengan kebenaran.

\section{Memimpin di Saat Sulit}

Besar kemungkinan seorang pemimpin akan mengalami saat sulit dan melelahkan ketika dia mencoba untuk memimpin orang lain. Kepemimpinan dapat saja menjadi tugas yang tidak menghasilkan rasa terima kasih, bahkan akan mengalami kesepian dan melemahkan semangat, hanya karena pemimpin menjadi sasaran kritik bahkan dapat juga ia akan merasa diserang ketika sedang memimpin. Patut diingat bahwa pemimpin maupun orang yang dipimpin tetaplah manusia biasa. Ini berarti bahwa pemimpin akan menghadapi konflik sebelum perjalanan kepemimpinannya usai. Semua orang memiliki cara pAndang (perspektif), kepribadian dan pergumulan yang berbeda-beda, sehingga mengakibatkan mereka bereaksi dengan cara mereka sendiri.

Umumnya sumber konflik dan kesulitan yang terjadi dalam hubungan antar manusia, antara lain sebagai berikut.

1. Benturan kepribadian.

2. Harapan yang tidak terungkap dan belum terpenuhi.

3. Perasaan tidak aman dan persoalan jati diri.

4. Konflik yang belum terselesaikan dari luka masa lalu.

5. Sikap independen dan cara pAndang yang kaku. 
Prinsip dasar yang harus dipahami oleh para pemimpin sebagai berikut.

1. Dalam hubungan antar manusia, para pemimpin sering kali harus mempraktikkan prinsip 101\%; Temukan 1\% orang yang setuju dengan Anda dan berikan 100\% perhatian Anda kepadanya.

2. Dalam hubungan antar pribadi, lebih baik membangun pagar di puncak karang dari pada membangun sebuah rumah sakit di bagian dasar. Ambil langkah untuk mencegah munculnya potensi kesulitan.

3. Ketika emosi yang diekspresikan dipandang jauh lebih penting dari pada masalah yang ada di depan mata, sudah pasti ada masalah tersembunyi yang harus dihadapi.

4. Ketika kebutuhan emosi seseorang dipandang perlu mengatasi akal sehat, itu tidak akan pernah masuk akal.

5. Orang yang terluka secara alamiah akan melukai orang lain.

6. Sebagai pemimpin, jangan sekali-kali kita menggantungkan kesehatan emosi kita di tangan orang lain.

7. Adalah mungkin bagi seorang pemimpin untuk mensabotase dirinya sendiri. Dia mungkin saja dapat memenangkan sebuah perdebatan, namun pada akhirnya dia akan mengalami kerugian yang lebih besar dari pada yang dapat diperolehnya.

8. Kita harus mempraktekkan hukum koneksi: para pemimpin akan menyentuh hati terlebih dahulu sebelum meminta uluran tangan.

Di dalam menghadapi orang yang sulit, apa yang dapat kita lihat di atas permukaan mereka adalah kelakuan dan kebiasaan. Orang dapat menjadi sumber konflik atau luka hati karena ada sesuatu yang tidak beres dalam hidup mereka. Kita tidak harus menggali terlalu jauh dalam suatu percakapan dengan mereka untuk menemukan sikap dan perasaan yang negatif, seperti kemarahan dan depresi. Jika kita menyelidiki mereka sedikit lebih jauh saja, maka kita akan mulai melihat ketidak mampuan orang-orang itu untuk mengampuni. Pada umumnya orang punya perasaan negatif karena mereka belum sanggup untuk mengampuni seseorang atau melepaskan kenangan buruk dari masa lalunya. Jika kita menggalinya lebih dalam lagi, maka kita akan menemukan kebutuhankebutuhan yang tidak terpenuhi. Harapan (expectation) itu ada yang diucapkan, tapi ada pula yang tidak diucapkan. Jelas, mereka mengharap seseorang untuk memenuhi kebutuhan itu. Pengikut memerlukan "sesuatu" dari pemimpinnya (followers need something from their leaders).

Namun, pada akhirnya akar dari masalah itu adalah rasa layak atas diri sendiri. Orang itu tidak percaya bahwa dirinya berharga dan ia berusaha mencari cara-cara tidak sehat untuk menutupinya. Mungkin mereka akan memicu konflik, mencari perhatian, mengalami depresi, tidak bersahabat, suka memaksa, terlalu sensitif, takut, tidak tahu berterima kasih, atau dingin, karena merasa tidak layak.

Sementara para pemimpin bertambah matang, mereka akan memahami dengan lebih baik perbedaan manusia. Mereka menyadari bahwa orang yang mengikuti mereka dimotivasi oleh sebab yang berbeda-beda, menanggapi ide-ide yang beraneka ragam, dan 
bersemangat karena alasan yang berbeda-beda. Setiap pemimpin harus mempelajari perbedaan-perbedaan kepribadian yang mendasar ini dalam organisasi mereka. Bila pemimpin tidak berhasil memahami dan tidak menjalin hubungan dengan kepribadian yang berbeda-beda di dalam organisasinya, akan muncul masalah. Ada empat macam kepribadian, antara lain sebagai berikut.

\section{Sanguin}

Mereka ingin diperhatikan dan merindukan agar segalanya menyenangkan. Tempat kerjanya sedikit amburadul, suka menguasai orang, baik dalam pembicaraan maupun kegiatan.

\section{Melankolis}

Bila melakukan sesuatu, mereka ingin hasilnya benar/tepat (perfect). Tempat kerjanya rapi. Mereka bekerja dengan sangat rinci dan dipikirkan sebelumnya. Biasanya mereka agak sedikit murung.

\section{Kolerik}

Biasanya mereka perkasa dan ingin memegang tanggung jawab. Mereka menginginkan hasil kerjanya dicapai dengan cara mereka. Mereka sangat menuntut dan kurang sabar.

\section{Flegmatis}

Mereka suka damai, gampang menyesuaikan diri dan sikapnya santai. Tempat kerjanya tidak formal serta sederhana. Mereka cenderung tidak disiplin waktu dan lamban.

\section{Mendelegasikan Tugas}

Ketika seseorang menjadi pemimpin, dia harus membuat keputusan yang mungkin dapat dianggap revolusioner untuk mengembangkan institusinya. Ia tidak lagi mengevaluasi bagaimana menyelesaikan tugas seorang diri, tetapi bagaimana menyelesaikan tugas melalui orang lain. Bila pemimpin merasa harus menyelesaikan segala sesuatu sendirian, maka ia akan merasa letih. Itulah sebabnya dia harus membuat perubahan serta memperlengkapi orang lain, kemudian membagi tanggung-jawabnya.

Ada beberapa langkah perubahan untuk menjadi seorang pemimpin. Ia harus mampu meng-komunikasikan kepada orang lain apa yang harus mereka lakukan, membentangkan visinya serta membuat rencana. Memilih di antara orang-orangnya untuk dilatih menjadi pemimpin dan memberi mereka kebebasan sesuai dengan kemampuan serta karunia yang dimilikinya. Namun tidak semua pekerjaan dapat didelegasikan, ada sebagian yang harus dikerjakan pemimpin itu sendiri. Sasaran pemimpin bukan memenuhi kebutuhan banyak orang secara langsung, tetapi memberdayakan orang lain untuk memenuhi banyak orang. Ia tidak lagi berfokus pada kebutuhan sekarang, tapi berfokus pada visi jangka panjang. Mengapa kadang-kadang para pemimpin gagal dalam 
mengembangkan orang lain? Sebagian karena mereka merasa hanya mereka sendiri yang memenuhi syarat untuk melakukannya. Mereka tidak mempercayai atau memAndang rendah orang lain. Penyebab utamanya, mereka tidak tahu bagaimana memilih dan melatih orang lain. Mengembangkan orang lain akan memakan energi dan waktu serta membutuhkan perencanaan yang matang. Ini merupakan suatu cara kepemimpinan yang proaktif dan bukan hanya menjalankan organisasinya seperti apa yang terjadi sebelumnya.

\section{PENUTUP}

Pemimpin membutuhkan visi, yang akan selalu memberi petunjuk saat melaksanakan pekerjaannya. Apabila banyak peristiwa yang menekan mulai muncul, jika tanpa visi maka ia tidak akan lama menjadi pemimpin. Semua pemimpin yang efektif punya suatu visi tentang apa yang akan mereka capai. Visi menjadi energi dibalik setiap usaha dan menjadi daya pendorong semangat yang menular yang dapat dirasakan ditengah orang banyak sampai orang-orang lain ikut bangkit dan mengikuti sang pemimpin.

Kesatuan dan kesamaan visi sangat penting agar impian dapat menjadi kenyataan. Jam-jam kerja yang panjang dan melelahkan akan dilaksanakan dengan suka rela agar tujuan tercapai. Urusan pribadi dikesampingkan, demi mencapai tujuan. Waktu berlalu dengan cepat, semangat dan moral membubung tinggi, bila pemimpin mempunyai visi. Tanpa visi, semangat dan energi akan menyurut, agenda pribadi mulai muncul, produksi jatuh dan orang-orang akan tercerai-berai. Visi menjadi ciri khas organisasi, baik bisnis, industri, pendidikan, sosial dan sebagainya. Visi merupakan pernyataan yang jelas dalam dunia yang penuh persaingan, dimana pemimpin mempunyai sudut pAndang yang penting di tengah hingar-bingar dunia dan demi eksistensi organisasi yang dipimpinnya. Visi juga menjadi alat kontrol dan kunci yang sekaligus menjaga agar semua orang terfokus arahnya. 


\section{DAFTAR PUSTAKA}

Baldoni, J. 2003. Great Communication Secrets of Great Leaders. Jakarta: PT Bhuana Ilmu Populer.

Danzig, R. and H. Kaplan. 1998. The Leader Within You. Hollywood, Florida: Frederick Fell Publishers, Inc.

Eims, L., 1981. 12 Ciri Kepemimpinan Yang Efektif. Bandung: Yayasan Kalam Hidup.

Kotter, J. P.1996. Leading Change. USA: Harvard Business School Press.

Lowney, C. 2005. Heroic Leadership. Jakarta: Penerbit PT Gramedia Pustaka Utama.

Maxwell, J. C. 1982. Mengembangkan Kepemimpinan di Dalam Diri Anda. Jakarta: Equipp.

Zenger, J. H. dan J. Folkman, 2004, The Handbook for Leaders. Jakarta: PT Bhuana Ilmu Populer, Kelompok Gramedia. 